\title{
The Effect of Policy Implementation of Law Number 33 of 2004 concerning Central and Regional Financial Balance on the Performance of the Regional Government of Banten Province
}

\author{
Andi Ahmad Dara \\ Universitas Pasundan Bandung, Indonesia \\ Email: andidara@gmail.com
}

\begin{abstract}
The purpose of this study is to analyze and find out how much influence the implementation of the central and regional financial balance policies, either partially or simultaneously, has on the performance of local government development in Banten Province. The population in this study were employees of the Banten Province Government Work Unit from echelon I to echelon IV as many as 888 employees with 90 samples taken by purposive sampling method. Data testing is done by using path analysis. The results show that the $X$ to $Y$ structure is the influence of the policy implementation variable $(X)$ on the performance variable of the Banten Provincial Government $(Y)$ with Path Analysis of $67.9 \%$, and the influence value outside the model is $32.1 \%$, where the value of the multiple correlation coefficient $R=0.824$, it can be stated that the degree of influence is very close compared to other variables not examined, and in the sub-structures $X_{1}, X_{2}, X_{3}$, and $X_{4}$ to $Y$, the influence of aspects of policy implementation are aspects of policy content $(X 1)$, information $\left(X_{2}\right)$, support $\left(X_{3}\right)$ and the distribution of potential $\left(\mathrm{X}_{4}\right)$ on Government performance of Banten Province $(\mathrm{Y})$ with Path Analysis of $67.9 \%$ and the influence value outside the model is $32.1 \%$ where the multiple correlation coefficient value $R=0.824$ can be stated the degree of influence is very close compared to the other variables. Others not investigated.
\end{abstract}

Keywords: Policy Implementation, Central and Regional Financial Balance, Performance, Regional Government.

\section{A. INTRODUCTION}

The implementation of regional autonomy is an expectation of the implementation of development in managing, developing, and developing regions according to their needs and potential (Suparman, 2019). To realize the implementation of this regional autonomy, the House of Representatives (DPR) has enacted law number 33 of 2004 concerning Financial Balance between Central and Regional Governments (Putriani, 2013). Law Number 23 of 2014 concerning Regional Government, which means that local governments are authorized to regulate and manage their own government affairs according to the principles of autonomy and co-administration (Edward, 2016) by applying the principles of good governance (Rasul, 2009). Granting broad freedom to regions accompanied by fiscal decentralization (Chistia \& Ispriyarso, 2019), directed at accelerating the realization of community welfare through service improvement, empowerment and community participation. 
According to Halim (2009), Sumardi (2015), and Sumardjoko (2018) in the implementation of regional autonomy, one of the criteria to know in real terms the implementation of fiscal decentralization is self-supporting in the financial sector. Regional financial issues are one of the main elements in implementing regional autonomy (Haryanto, 2015). However, it is recognized that various other variables also affect regional financial capabilities, such as quality human resources, organization, management, facilities, and budget planning (Sumardjoko, 2018). Financial capability in the administration of a government is very important, as a function of regional fiscal independence (Setiawan, 2007; Seymour, 2002; Siregar, 2017), because local governments will not be able to carry out their functions effectively and efficiently without sufficient costs to provide development and financial services in their management.

The ability of regional finances to manage their finances is stated in the APBD, which describes the ability of provincial governments to finance the activities of implementing co-administration tasks as a form of fiscal decentralization (Kharisma, 2013; Kuncoro, 2007; Kurniawan, 2012). In carrying out regional autonomy, local governments are required to run the wheels of government effectively and efficiently, be able to encourage community participation in development, and increase equity and justice by developing all the potentials possessed by each region (Magriasti, 2011; Makhfudz, 2013; Putriani, 2013). Indicators of local government financial capacity are the ratio of regional financial independence, activity ratio, effectiveness ratio, and growth ratio. In comparison, local government financial performance indicators are the ratio of the degree of fiscal autonomy and index Routine Ability (IKR).

By Law Number 33 Year 2004, article 10 states that the sources of financing for regional development (capital investment), among others, come from balancing funds consisting of Revenue Sharing Funds, General Allocation Funds (DAU), Special Allocation Funds (DAK), and Revenues. Original Region (PAD). The results of this financial ratio analysis then become a benchmark for assessing regional financial independence, effectiveness, the contribution of each source in the formation of regional income, and seeing the growth/development of income and expenditure acquisitions carried out over a certain period (Halim, 2012).

The ratio of the effectiveness of districts and cities in Banten Province mostly shows very effective results (> 100\%) where the Regency Government (regency) and City Government (Pemkot) have been able to collect all sources of regional income except for Pandeglang Regency, which has not been effective $(<100 \%)$ due to have not been able to utilize all sources of regional income. The ratio of activity in each district and city in Banten Province shows that the majority of local governments and city governments spend more on APBD funds for indirect expenditures. Except for Tangerang Regency, Cilegon City, Tangerang City, South Tangerang City, they spend more of their APBD for direct spending. The growth ratio from Table 1.2 can be seen from each growth showing low results where PAD growth, total spending growth, indirect spending growth, and district/city direct spending growth in Banten Province $<50 \%$. Except for South Tangerang City, where direct spending grew by $56 \%$. 
The government performance of Banten Province work unit has not been realized optimally. The implementation suspects it of local government policies in the balance of central and regional finances that have not run optimally. The essence of the implementation of local government policies in the proportion of central and regional finances in the province of Banten is intended to improve the development performance of local governments, particularly related to the function of regional budget governance that can help the success of overall development. The researchers' argument above strengthens them to conduct an in-depth study through thesis research with the title: "The Influence of Central and Regional Financial Balance Policy Implementation on Government performance of Banten Province".

\section{B. LITERATURE REVIEW}

\section{Public Administration}

According to Dimock in Suradinata (1993), "the administration process is an integral part of the nation's political process." In the political context, public administration plays a very important role in the formulation of state policies. This is stated by Gordon \& Lontoh translation (1988) which states that: For the Letter of the twentieth century, the public bureaucracy has been the locus of public policy formulation and the primary determinant of where this country is going.

From this understanding, it appears that public administration includes state activities to achieve overall state policies. According to Atmosudirdjo (1982), public administration is defined as "the organization and administration of organizational units that pursue the achievement of state goals". Meanwhile, Kristadi (1994) states: "The purpose of the state as intended is an effort to realize the welfare of the people through the provision of various public goods and providing public services."

From this opinion, it appears that the state's goal is directed at welfare by providing excellent facilities and services to the community. Siagian (1994) explains administration as "all activities carried out by all government apparatus of a country in an effort to achieve the goals of the State".

\section{Public policy implementation}

According to Howlet \& Ramesh (1995), "It's defined as the process where by programs or policies are carried out; it denotes the translation of plants into practice". The same thing was stated by Van Meter and Van Horn in Nugroho (2004) that "policy implementation is actions taken either by individuals, officials or groups of government or private groups directed towards achieving the goals outlined in the decision policy". Referring to the opinion above, it can be seen that a public policy actually requires the involvement of various parties, not only carried out by the government, including the private sector as well. The target of public policy is the wider community so that at the implementation stage, it cannot be done alone.

According to Nugroho (2004) that, "policy implementation in principle is a way for a policy to achieve its goals. Nothing more and nothing less." This opinion provides an understanding that the implementation of the policy sees how the policy 
can be implemented. The implementation of the policy in principle is a way for a policy to achieve its goals. No more and no less.

\section{Public Organization Performance Concept}

Prawirosentono (1999) defines performance as performance, namely the results of work that can be achieved by a person or group of people in an organization, in accordance with their respective authorities and responsibilities, in an effort to achieve the goals of the organization concerned legally, not violating the law. And in accordance with morals and ethics.

The definition of organizational performance put forward by Bastian in Tangkilisan (2005) is a description of the level of achievement of the implementation of tasks in an organization in realizing the goals, objectives, mission, and vision of the organization. From some of the definitions above, it can be concluded that performance is an achievement or result of work in activities or activities or programs that have been previously planned in order to achieve the goals and objectives set by an organization and carried out within a certain period.

The previous research table, as presented below, can be explained that the results of previous studies provide a deeper understanding and insight to researchers both in theoretical and empirical settings.

\section{METHOD}

This research was conducted using a quantitative approach with data analysis carried out through statistical tests after collecting the data through research questionnaires. Data testing is done by using path analysis (Path Analysis). The population in this study were employees of the Banten Provincial Government Work Unit from echelon I to echelon IV, as many as 888 employees. Sampling was done by the purposive sampling method. Seville et al. (1960: 182) suggested that calculating the sample size can be done using the Slovin technique, and it was found that there were 90 respondents. The variables in the study describe the structured relationship of the variables comprehensively, namely Policy Implementation (X), with Organizational Performance (Y).

Based on the picture of the correlation between the variables of Policy Implementation $(X)$ to Organizational Performance $(Y)$, it can be seen that the magnitude of the path coefficient between the independent variables and the dependent variable is Policy Content (X1), Information (X2), Support (X3), and Potential Distribution (X4) to Organizational Performance $(\mathrm{Y} \varepsilon)$, the arranged data is formed by ordinal data and then transformed into interval data using the Method of Successive interval. After that, the score values for the variables are accumulated, and the final stage is calculated using path analysis. 


\section{RESULT AND DISCUSSION}

\section{Validity Test}

The results of the validity test on the policy implementation variable $(X)$ are as follows:

Table 1 Variable Policy Implementation (X) Validity Test Results

\begin{tabular}{|c|c|c|c|}
\hline Item & $\mathbf{r}$ & $\mathbf{r}$ table & Decision \\
\hline 1 & 0,459 & 0,361 & Valid \\
\hline 2 & 0,626 & 0,361 & Valid \\
\hline 3 & 0,598 & 0,361 & Valid \\
\hline 4 & 0,440 & 0,361 & Valid \\
\hline 5 & 0,606 & 0,361 & Valid \\
\hline 6 & 0,674 & 0,361 & Valid \\
\hline 7 & 0,622 & 0,361 & Valid \\
\hline 8 & 0,650 & 0,361 & Valid \\
\hline 9 & 0,620 & 0,361 & Valid \\
\hline 10 & 0,444 & 0,361 & Valid \\
\hline 11 & 0,763 & 0,361 & Valid \\
\hline 12 & 0,712 & 0,361 & Valid \\
\hline 13 & 0,552 & 0,361 & Valid \\
\hline 14 & 0,558 & 0,361 & Valid \\
\hline 15 & 0,632 & 0,361 & Valid \\
\hline
\end{tabular}

Source: Data Processing Results, 2020

Based on the table above, it can be seen that the instrument test for the Policy Implementation Variables shows that all statements are valid so that all data can be continued to the following analysis.

The validity test for the $\mathrm{Y}$ variable (government performance), which consists of 14 statement items, is all valid. The calculation results are described in the following table:

Table 2 Variable Government Performance (Y) Validity Test Results

\begin{tabular}{|c|c|c|c|}
\hline Item & $\mathbf{r}$ & $\mathbf{r}$ table & Decision \\
\hline 16 & 0,665 & 0,361 & Valid \\
\hline 17 & 0,676 & 0,361 & Valid \\
\hline 90 & 0,639 & 0,361 & Valid \\
\hline 19 & 0,774 & 0,361 & Valid \\
\hline 20 & 0,466 & 0,361 & Valid \\
\hline 21 & 0,649 & 0,361 & Valid \\
\hline 22 & 0,631 & 0,361 & Valid \\
\hline 23 & 0,706 & 0,361 & Valid \\
\hline 24 & 0,759 & 0,361 & Valid \\
\hline 25 & 0,702 & 0,361 & Valid \\
\hline 26 & 0,643 & 0,361 & Valid \\
\hline 27 & 0,710 & 0,361 & Valid \\
\hline
\end{tabular}




\begin{tabular}{|l|l|l|l|}
\hline 28 & 0,646 & 0,361 & Valid \\
\hline 29 & 0,694 & 0,361 & Valid \\
\hline
\end{tabular}

Source: Data Processing Results, 2020

The value of the $r$ table refers to table $r$ for product-moment correlation and determines the magnitude of $=0.05$ and $n=30$. Based on these calculations, the value of the $r$ table $=0.361$; after comparing the value of the $r$ table is smaller than the $r$ count, it can be concluded that the government performance variable data Banten Province $(\mathrm{Y})$ is valid.

\section{Reliability Test}

Based on the results of data calculations, the reliability coefficient decisions obtained from each variable are as follows:

Table 3 Research Instruments Reliability Test Results

\begin{tabular}{|c|l|c|c|c|}
\hline No & \multicolumn{1}{|c|}{ Research variable } & Reliability & ${ }^{*}$ ) Reference & Decision \\
\hline 1 & Policy implementation $(\mathrm{X})$ & 0.907 & $+0.89-+1.00$ & Strong Reliable \\
\hline 2 & Government Performance $(\mathrm{Y})$ & 0.905 & $+0.89-+1.00$ & Strong Reliable \\
\hline
\end{tabular}

Source: Data Processing Results, 2020

This reliability test result indicates that all instruments used to measure all items of the policy implementation variables and government performance of Banten Province can be accepted for reliability or consistency.

\section{Policy Implementation Variables}

The implementation of this policy consists of four aspects, namely policy content, information, support, and potential sharing. To determine the condition of the policy implementation variables, measurements were made using a questionnaire consisting of 15 questions, each accompanied by five possible answers that must be selected and deemed appropriate according to the respondent.

a. Policy content aspect

Based on the calculation of the questionnaire results on the policy content aspect, the score is on $\Sigma \mathrm{fi} . \mathrm{Xi}=1170$, and this score is between the answers in the high aspect to very high, so it can be said that the policy content aspect in the implementation of this policy is excellent.

b. Information Aspect

Based on the calculation of the questionnaire results on the information aspect, the score is on $\Sigma$ fi. Xi $=1431$, and this score is between the answers in the medium to high aspect, so it can be said that the information aspect in the implementation of this policy is good.

c. Support Aspect

Based on the calculation of the questionnaire results on the aspects of support possessed by the employees, the score is on $\Sigma \mathrm{fi} . \mathrm{Xi}=1920$, and this score is between the answers in the high aspect to very high, so it can be said that the support aspect in implementing this policy is excellent. 
d. Potential Sharing Aspect

Based on the calculation of the questionnaire results on the aspect of potential distribution, the score is on $\Sigma \mathrm{fi} . \mathrm{Xi}=1145$, and this score is between the answers in the high to very high aspect, so it can be said that the potential distribution aspect in implementing this policy is excellent.

\section{Government Performance Variable of Banten Province}

The following variable presented by the results in this study is the Government performance variable of Banten Province, which is divided into five factors, namely productivity, service quality, responsiveness, responsibility, and accountability, with fourteen statement items in the form of positive statements.

a. Productivity Factor

Based on the calculation of the questionnaire results on the productivity factor, the score is on $\Sigma$ fi.Xi $=1153$, and this score is between the answers on the high factor to very high, so it can be said that the productivity factor in the Government performance of Banten Province has gone very well.

b. Service Quality Factor

Based on the calculation of the questionnaire results on the service quality factor, the score is on $\Sigma \mathrm{fi} . \mathrm{Xi}=771$, and this score is between the answers on the high factor to very high, so it can be said that the service quality factor in the Government performance of Banten Province has gone very well.

c. Responsiveness Factor

Based on the calculation of the questionnaire results on the responsiveness factor, the score is on $\Sigma \mathrm{fi} . \mathrm{Xi}=1122$, and this score is between the answers on the high factor to very high, so it can be said that the responsiveness factor in the Government performance of Banten Province has gone very well.

d. Responsibility Factor

Based on the calculation of the questionnaire results on the responsibility factor, the score is on $\Sigma \mathrm{fi} . \mathrm{Xi}=1480$, and this score is between the answers on the high to very high factor, so it can be said that the responsibility factor in the Government performance of Banten Province has gone very well.

e. Accountability Factor

Based on the calculation of the questionnaire results on the accountability factor, the score is on $\Sigma \mathrm{fi} . \mathrm{Xi}=729$, and this score is among the answers on the moderate to high factor, so it can be said that the accountability factor in the Government performance of Banten Province has gone well.

\section{Variable Structure $X$ to $Y$}

In the structure of variables $X$ to $Y$, it is tested how much influence the policy implementation variable has on the Government performance variable of Banten Province with Path Analysis. The calculation results show the coefficient of determination $\left(\mathrm{R}^{2}\right)$ of 0.679 means that $67.9 \%$ of the Government performance variable of Banten Province can be explained by the independent variable, in this case, the 
policy implementation, which also means that there is an effect of policy implementation on the Government performance of Banten Province of the coefficient of determination $\left(\mathrm{R}^{2}=67.9 \%\right)$ or $67.9 \%$ this can also mean that the influence of the variables outside the model is $\rho_{y \varepsilon}=1-\mathrm{R}^{2}=0.321$ (error). This multiple determination value is the square of the multiple correlation coefficient values $R=0.824$. This $R^{2}$ value indicates that the degree of influence of policy implementation is very close when compared to other variables not examined.

\section{Sub Structure $X 1, X 2, X 3$, and $X 4$ to $Y$}

In this substructure, it is tested how much influence aspects of policy implementation, namely aspects of policy content (X1), information (X2), support (X3), and potential distribution (X4) on the Government performance of Banten Province $(\mathrm{Y})$ in Kiaracondong District, Bandung City with Path Analysis. The calculation results explain that the coefficient of determination $\left(R^{2}\right)$ is 0.679 , this means that $67.9 \%$ of the variability of the Government performance variable of Banten Province can be explained by independent variables in this case, aspects of policy content (X1), information (X2), support (X3) and potential distribution (X4), which can also be interpreted that there is a joint influence between aspects of policy content $(\mathrm{X} 1)$, information $(\mathrm{X} 2)$, support $(\mathrm{X} 3)$, and potential distribution $(\mathrm{X} 4)$ on the Government performance of Banten Province of the coefficient of determination (R2 $=67.9 \%$ ) or this can also mean that the influence of variables outside the model is $1-$ $\mathrm{R}^{2}=0.321$ (error).

Referring to the multiple correlation coefficient for the structure being tested, the coefficient of multiple determination and all exogenous variables tested is $\mathrm{R}^{2}=$ $67.9 \%$; this multiple determination value is the square of the multiple correlation coefficient value $R=0.824$. This $R^{2}$ value indicates that the degree of influence of aspects of policy content (X1), information (X2), support (X3), and potential distribution (X4) is very close when compared to other variables not examined.

\section{E. CONCLUSION}

The contents of the policy in implementing the central and regional financial balance policy have been implemented well; this is reflected in the total score of respondents' responses which are included in good criteria. Partially the implementation of the central and regional financial balance policy on the subvariables of the policy content has a significant effect on improving the performance of the Banten Province SKPD. The level of information in implementing the central and regional financial balance policies is good; this is reflected in the total score of respondents' responses included in good criteria. Partially the implementation of the central and regional financial balance on the information level sub-variables has a significant effect on improving the performance of the Banten Province SKPD, and the amount of support in the implementation of central and regional financial policies is good; this is reflected in the total score of respondents' responses which are included in good criteria. Partially the implementation of the central and regional financial 
balance policy on the sub-variables, the amount of support has a significant effect on improving the performance of the Banten Province SKPD.

\section{REFERENCES}

1. Arief, I. (2015). Pengaruh Pendapatan Asli Kabupaten/Kota, Dana Alokasi Umum, Dana Otonomi Khusus dan Dana Bagi Hasil terhadap Kinerja Keuangan Kabupaten/Kota Pemekaran di Provinsi Aceh. Jurnal Telaah dan Riset Akuntansi, 8(2), 109-118.

2. Christia, A M., \& Ispriyarso, B. (2019). Desentralisasi Fiskal dan Otonomi Daerah di Indonesia. Law Reform Journal, 15(1).

3. Edward, H. (2016). Perimbangan Keuangan Antara Pemerintah Pusat Dengan Pemerintah Daerah Salam Pengelolaan Keuangan Daerah. Jurnal Ilmu Pemerintahan Widyapraja, XLII(1).

4. Grindle, M. S., \& John W. Thomas, 1980, Public Choices and Policy Change: The Political Economy of Reform in Developing Countries. London: John Hopkins University Press.

5. Halim, A. (2009) Problem Desentralisasi dan Perimbangan Keuangan Pemerintah Pusat Daerah: Peluang dan Tantangan dalam Pengelolaan Sumber Daya Daerah. Yogyakarta: Sekolah Pascasarjana UGM.

6. Howlett, M., \& M. Ramesh. (1995). Studying Public Policy: Policy Cycles and Policy Subsystems. Oxford: Oxford University Press.

7. Kharisma, B. (2013). Desentralisasi Fiskal dan Pertumbuhan Ekonomi: Sebelum dan Sesudah Era Desentralisasi Fiskal di Indonesia. Jurnal Ekonomi dan Studi Pembangunan, 14(2), 101-119.

8. Halim, A. (2009). Problem Desentralisasi dan Perimbangan Keuangan Pemerintah PusatDaerah: Peluang dan Tantangan dalam Pengelolaan Sumber Daya Daerah. Yogyakarta, Sekolah Pascasarjana UGM.

9. Kuncoro, M. (2007). Otonomi dan Pembangunan Daerah. Jakarta: Erlangga.

10. Kurniawan, D. (2012). Otonomi Daerah dan Desentralisasi Fiskal di Indonesia. EJurnal Unisfat, 7(2), 129-144.

11. Magriasti, L. (2011). Arti Penting Partisipasi Masyarakat dalam Kebijakan Publik di Daerah: Analisis dengan Teori Sistem David Easton. Jurnal Proceding Simsposium Nasional Otonomi Daerah. LAB-ANE FISIF Untirta, 1(1), 252-258.

12. Makhfudz, M. (2013). Kontroversi Pelaksanaan Otonomi Daerah. Jurnal Hukum, 3(2), 380-407.

13. Mazmanian, D. A., \& Sabatier, P. A. (1983). Implementation and Public Policy. London: Scott, Foresman, and Company.

14. Nugroho, D. R. (2004). Kebijakan Publik, Formulasi, Implementasi dan Evaluasi. Jakarta: Gramedia.

15. Nuryadin, D., \& Suharsih, S. (2017). Analisis dan evaluasi dampak dana alokasi khusus terhadap indikator kinerja pembangunan di daerah studi kasus kabupaten-kota 2003-2013. Jurnal Ekonomi \& Studi Pembangunan, 18(1), 62-70. 
16. Pradiptyo, R. Suprayitno, B. (2017) Fiscal decentralization and corruption: The facts in regional autonomy in Indonesia. Journal Advanced Research of Law and Economics, 8(5), 1458-1468.

17. Psycharis, Y., \& Yoi, M. (2015). Decentralization and local government fiscal autonomy: evidence from the Greek municipalities. Environment and Planning C: Government and Policy, 34(2), 262-280.

18. Putriani, D. (2013). Analisis Implementasi Kebijakan Perimbangan Keuangan Antara Pemerintah Pusat Dan Pemerintah Daerah Dalam Era Otonomi Daerah di Kota Palu. e-Jurnal Katalogis, I(2), 59-66

19. Rasul, S. (2009). Penerapan Good Governance di Indonesia Dalam Upaya Pencegahan Tindak Pidana Korupsi. Mimbar Hukum, 1(3), 538-553.

20. Rompas, J. F., Pati, A. B., \& Lengkong, J. P. (2017). Implementasi Kebijakan Pengelolaan Keuangan Desa di Kecamatan Langowan Utara Kabupaten Minahasa. Jurnal Eksekutif, 1(1).

21. Setiawan, B., \& Hadi, S. P. (2007). Regional Autonomy and Local Resource Management in Indonesia. Asia Pacific Viewpoint, 48(1), 72-84.

22. Seymour, R., \& Turner, S. (2002). Otonomi Daerah: Indonesia's Decentralisation Experiment. New Zealand Journal of Asian Studies, 4(2), 33-51.

23. Siregar, B., \& Pratiwi, N. (2017. The Effect of Local Government Characteristics and Financial Independence on Economic Growth and Human Development Index in Indonesia. Jurnal Manajemen dan Kewiraushaan, 19(2), 65-71.

24. Sumardi. (2015). Determinan Efektifitas pengaruh Kebijakan Desentralisasi Fiskal Terhadap Kemampuan Keuangan Daerah serta Dampaknya Pada Ekonomi Pertumbuhan Daerah (Studi Kasus: Kabupaten/Kota di Jawa Tengah). Journal of Rural and Development, V(2), 147-165.

25. Sumardjoko, Imam. 2018. Akurasi Perencanaan Tugas Pembantuan dan Dana Transfer Khusus serta Implikasinya terhadap Capaian Output. Jurnal Defis, III.

26. Suparman, N., Chandra, D., \& Sari, A. L. (2019). Bureaucratic Behavior in the Implementation of Capital Expenditure Budget in the Office of Public Works and Spatial Planning of Sumedang Regency. Jurnal Bina Praja: Journal of Home Affairs Governance, 11(1), 99-109.

27. Tangkilisan, H. N. S. (2005). Manajemen Publik. Jakarta: Gramedia Widia Sarana Indonesia.

28. Yakub, A., Ghani, A. B. A., \& Anwar, M. S. I. (2018). Urgency of political decentralization and regional autonomy in Indonesia: Local perspectives. Journal of International Studies, 14, 141-150. 